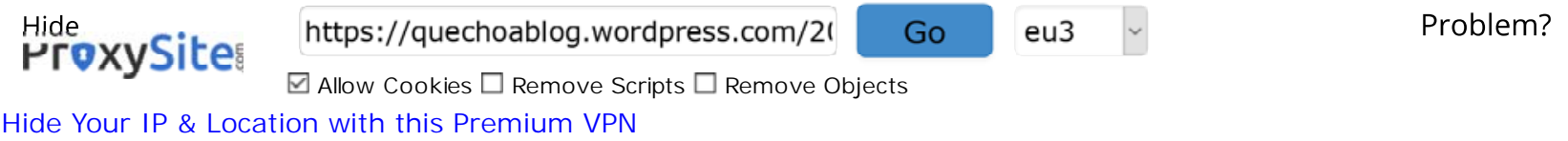

\title{
Quê choa
}

(blog cũ của nhà văn Nguyễn Quang Lập)

https:/quechoablog.wordpress.com/2011/10/23/khong-d\%C6\%A1n-gi\%E1\%BA\%A3n-ch\%E1\%BB $\% 89-b \% E 1 \%$ BB\%9Fi-long-tham/

\section{Không đơn giản chỉ bởi lòng tham}

\author{
Đào Tuấn
}
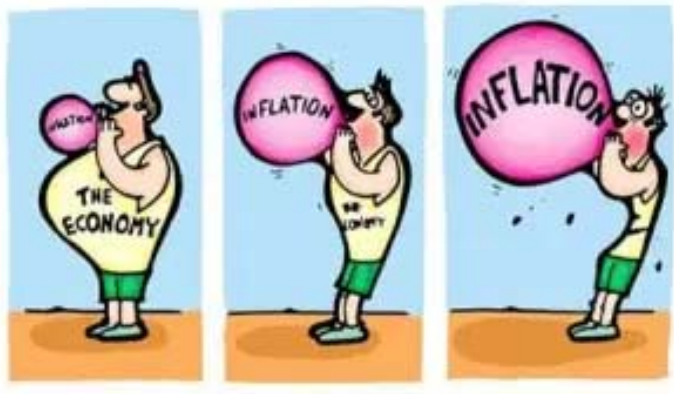

Khi các vụ vỡ nợ lớn nhỏ đua nhau đổ bể, người ta bắt nhắc lại vụ án nước hoa Thanh Hương hồi cuối nhi năm 80. Tháng 3-1990, khi vụ Thanh Hương đổ bể, số huy động trong dân chúng lên tới con số khủng khiếp tỷ đồng. Để dễ hình dung mức độ khổng lổ của con sć cơn sốc xã hội bấy giờ, có thể đối sánh với giá gạo, kho 900đ/kg, thu nhập bình quân đầu người khoảng 227 I và tỷ giá 4.500 đồng/USD.

“Phương thức nợ Thanh Hương" sau này được tổng kê "kiểu lừa rất cổ điển": Thương hiệu ảo- Lãi cao. Với 10. đồng lãi trên mỗi 1.000 .000 đồng vốn và một thương $r$ mà cứ mỗi giờ vàng lại có những ca sĩ nổi tiếng hát những bản nhạc được sáng tác riêng cho Thanh Hưc cả TP HCM lên cơn sốt khi dường như ai cũng là chủ nợ của Thanh Hương.

Bối cảnh của vụ án nước hoa Thanh Hương, và ngay trước đó là vụ đổ vỡ hàng loạt các HTX tín dụng, c là giai đoạn bất ổn nhất trong lịch sử kinh tế Việt Nam: Tỷ giá tồn tại phi thực tế và trong 9 năm đã $t$ 450 lần, từ 10 đồng/1 USD năm 1981 lên 4.500đ/1 USD tháng 3-1989. Do ảnh hưởng bởi giá lương tiền, $t$ siêu lạm phát xảy ra chưa từng có trong suốt các năm 1986- 1989. Từ kỷ lục về lạm phát 453,3\% năm 1 ! đến trước thời điểm Thanh Hương vỡ nợ, lạm phát "vẫn còn" 95,3\%. Cần phải nhấn mạnh là để đối phó lạm phát, Nhà nước bấy giờ cho....đổi tiền- nhấn mạnh thêm, là sau khi in tiền không xuể.

Cho tư nhân vay với lãi suất cao hơn lạm phát, rất đơn giản, chính là một hình thức giữ tiền của dân. Một nghiên cứu của tướng Công an Phạm Minh Chính, người đang đương chức Ủy viên TƯ Đảng, Bí tỉnh ủy Quảng Ninh nếu ví dụ: Năm 1988, 1 lô đất ở khu vực Láng Thượng (Đống Đa- HN) được giao dịch giá 2 chỉ vàng. 2 năm sau, lô đất này được giao dịch lại với giá 7 lượng vàng. Cao gấp 35 lần giá cũ. Đến $r$ 1993, giá đã là 120 cây vàng, gấp 17 lần giá 3 năm trước và 600 lần so với giá cách đó 5 năm. TS Chính rằng: Tâm lý muốn đảm bảo tiền bằng nhà và đất xuất hiện vào đầu những năm 90.

Sau vụ Thanh Hương, tâm lý trú ấn khiến người dân tiếp tục giữ tài sản của mình bằng cách đầu tư vào đai, và vàng, thay vì là gửi tiền vào ngân hàng như Nhà nước mong muốn. Không phải ngẫu nhiên là đ vào năm 1990, Việt Nam lần đầu tiên buộc phải cho nhập khẩu vàng. Không phải là ngẫu nhiên mà giá từ 1990 lên theo chiều thẳng đứng và cơn sốt đất đầu tiên xảy ra năm 1993.

Sách "Kinh tế Việt Nam: Thăng trầm và đột phá" của cặp đôi TS Phạm Minh Chính và Vương Quân Ho cho biết: Kinh tế tư nhân bấy giờ không tiếp cận được nguồn vồn ngân hàng, phổ biến là do không có 
sản thế chấp và chính sách không khuyến khích của Ngân hàng đối với những khoản vay này. KT tư nr trong điều kiện hầu bao bị bót nghẹt trông phần lớn vào hình thức "Hụi". Và lẽ đương nhiên, thị trường dụng phi chính thức ra đời, thậm chí rất phát triển, nhằm đáp ứng nhu cầu từ hai phía dư vốn và tr vốn.

Hụi họ, tín dụng phi chính thức vẫn tồn tại từ đó đến giờ như một kênh huy động vốn "dân gian". Và võ chỉ xảy ra khi nền kinh tế "có vấn đề".

Không khó để chỉ ra những vấn đề của nền kinh tế hiện nay và đó là những vấn đề đã từng tồn tại tr thập niên 80 của thế kỷ trước.

Khi nguồn vốn bị bóp nghẹt với lãi suất vượt quá định mức lợi nhuận thông thường, khi mà thị trư chứng khoán, kênh huy động vốn liên tục trong tình trạng đèn đỏ, mà con số gần 47 ngàn doanh ngr giải thể hoặc phá sản chỉ là một mặt của vấn đề, thì người ta phải trông chờ vào tín dụng đen, hoặc kh làm gì cả. Khi niềm tin vào đồng nội tệ suy giảm, người ta phải chuyển đổi tiền đồng vào đất, vào vàng, ngoại tệ. dù bất động sản đang đóng băng, dù vàng cao hơn giá thế giới cả triệu đồng mỗi lượng, dù tỷ thậm chí được "điều chỉnh" 3 lần trong chỉ 7 ngày. Và khi mà lạm phát cao hơn mức lãi suất ngân hàng cả chục \%, người ta sẵn sàng chấp nhận rủi ro với tín dụng phi chính thức để bảo toàn tài sản của mình. Đã có một cách nhìn nhận rất ác tâm xung quanh câu chuyện vỡ nợ: "Lòng tham và cả tin"; “Chung quy tại lòng tham"; “'Lòng tham đang được sát hạch"...

Nhưng vỡ nợ không đơn giản chỉ bởi lòng tham.

Nguyễn Văn Mười Hai đã ra tù và bắt đầu một cuộc đời mới. Nhưng chắc chắn những Mười $B a$, Mười I sẽ xuất hiện. Rất sớm thôi.

Theo blog Đào Tuấn

This entry was posted in Lưu on 23.10.2011

[/process.php?d=FAdztE2cYmcxH0kM1 qbaxGAps1Y8gmtanPr7vvOEtIN9C\%2BHHiYGNTJSz2obOn1s|4S16Q90QN QNXPiO9MYrufKJNOcbX30JDkCbTLPITLyUIHXCh4zNFNKgcCadyzqkVUajShzCA\%3D\%3D\&b=1] . 


\section{Tài liệu tham khảo:}

[1] Thanh Niên. (2007). 'Đại gia số một' Nguyễn Văn Mười Hai làm lại cuộc đời. VNExpress (12/7). https://vnexpress.net/dai-gia-so-mot-nguyen-van-muoi-hai-lam-lai-cuoc-doi2087254.html

[2] Phạm Minh Chính, Vương Quân Hoàng. (2009). Kinh tế Việt Nam: Thăng trầm và đột phá. NXB Chính trị quốc gia, Hà Nội.

[3] Vương Trần, Văn Chương. (2012). Xung quanh những vụ vỡ nợ: Lòng tham đang được sát hạch. Người Đưa Tin (28-12). https://www.nguoiduatin.vn/xung-quanh-nhung-vu-vono-long-tham-dang-duoc-sat-hach-a15677.html 